\title{
KCNQ2 Encephalopathy Manifesting With Rett-like Features
}

A Follow-up Into Adulthood

Neurol Genet 2021;7:e604. doi:10.1212/NXG.0000000000000604

In the Clinical/Scientific Note "KCNQ2 encephalopathy manifesting with Rett-like features: A follow-up into adulthood" by Mastrangelo et al., the first sentence of the fifth paragraph should read, "A next-generation sequencing panel that included 140 genes involved in genetic epilepsies revealed the de novo heterozygous $\mathrm{KCNQ} 2$ variant c.629 G > C (p.Arg210Pro), which was not present in the Human Gene Mutation Database (portal.biobase-international.com/)." The authors regret the error.

\section{Reference}

1. Mastrangelo M, Manti F, Giannini MT, Guerrini R, Leuzzi V. KCNQ2 encephalopathy manifesting with Rett-like features: a follow-up into adulthood. Neurol Genet. 2020;6(5):e510. 


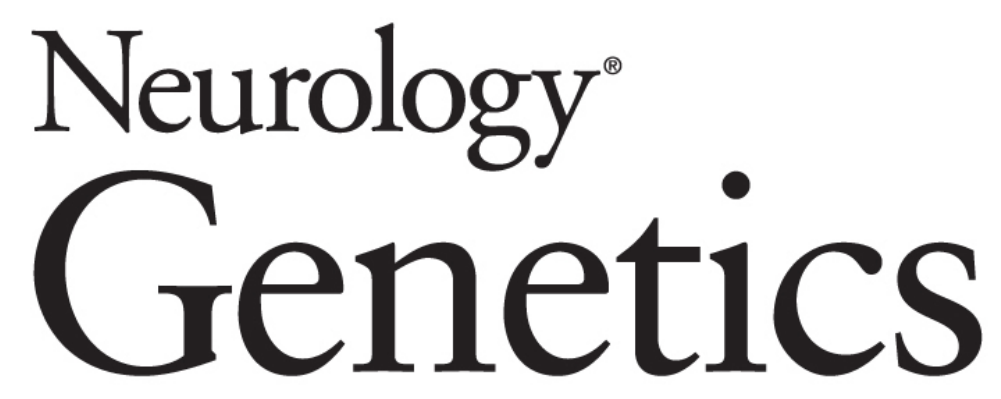

\section{KCNQ2 Encephalopathy Manifesting With Rett-like Features: A Follow-up Into Adulthood \\ Neurol Genet 2021;7; \\ DOI 10.1212/NXG.0000000000000604}

This information is current as of June 2, 2021

\section{Updated Information \& Services}

References

Permissions \& Licensing

Reprints including high resolution figures, can be found at: http://ng.neurology.org/content/7/4/e604.full.html

This article cites 1 articles, 1 of which you can access for free at: http://ng.neurology.org/content/7/4/e604.full.html\#\#ref-list-1

Information about reproducing this article in parts (figures,tables) or in its entirety can be found online at:

http://ng.neurology.org/misc/about.xhtml\#permissions

Information about ordering reprints can be found online: http://ng.neurology.org/misc/addir.xhtml\#reprintsus

Neurol Genet is an official journal of the American Academy of Neurology. Published since April 2015, it is an open-access, online-only, continuous publication journal. Copyright @ 2021 American Academy of Neurology. All rights reserved. Online ISSN: 2376-7839.

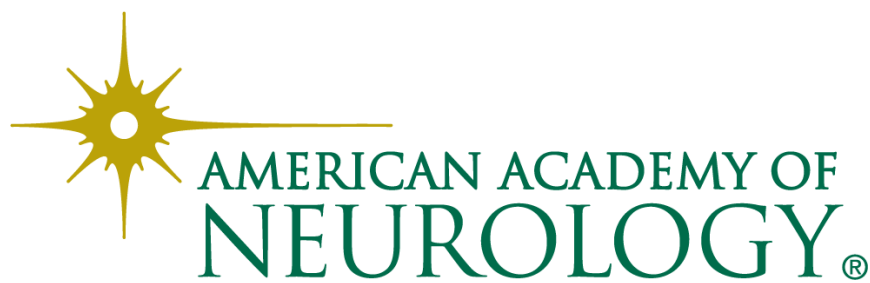

